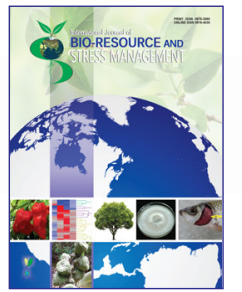

\title{
Willow Extract (Salix cortex), a Basic Substance of Agronomical Interests
}

\author{
M. G. Deniau1, R. Bonafos², M. Chovelon¹, C-E. Parvaud ${ }^{1}$, A. Furet ${ }^{3}$, C. Bertrand ${ }^{4}$ and P. A. Marchand ${ }^{1 *}$
}

${ }^{1}$ Institut de l'Agriculture et de l'Alimentation Biologiques (ITAB) Inputs Dept., 149 rue de Bercy, F- 75595 Paris CEDEX 12, France ${ }^{2}$ Montpellier SupAgro, Department of Biology and Ecology 2 Place Pierre Viala, F-34060 Montpellier, France

${ }^{3} \mathrm{ADABIO}, 95$ rue des Soudanières, F-01250 CEYZERIAT, France

${ }^{4}$ Universite de Perpignan Via Domitia (UPVD), CRIOBE Centre de Recherches Insulaires et Observatoire de l'Environnement (USR 3278), 52 avenue Paul Alduy, F-66860 PERPIGNAN Cedex 9, France

Open Access

\section{Corresponding Author}

P. A. Marchand

e-mail: patrice.marchand@itab.asso.fr

Citation: Deniau et al., 2019. Willow Extract (Salix cortex), a Basic Substance of Agronomical Interests. International Journal of Bio-resource and Stress Management 2019, 10(4):408-418. HTTPS://DOI. ORG/10.23910/IJBSM/2019.10.4.2009

Copyright: (c) 2019 Deniau et al. This is an open access article that permits unrestricted use, distribution and reproduction in any medium after the author(s) and source are credited.

Data Availability Statement: Legal restrictions are imposed on the public sharing of raw data. However, authors have full right to transfer or share the data in raw form upon request subject to either meeting the conditions of the original consents and the original research study. Further, access of data needs to meet whether the user complies with the ethical and legal obligations as data controllers to allow for secondary use of the data outside of the original study.

Funding: The author wishes to thank the French Ministry of Ecology (MEDDE) (CP ITAB PNPP V14 26-11-10, 2010-12), the French Ministry of Agriculture (MAAF) and DGER (Direction Generale de l'Enseignement et de la Recherche) for investigation projects on natural products properties (Casdar 4P).

Conflict of interests: No potential conflict of interest was reported by the authors.

Acknowledgement: The author wishes to thank Trevor M. Fenning for providing helpful advice on the editing and writing of the manuscript. The article is in Memoriam of Prof. Ratikanta Maiti

\section{Article History}

RECEIVED in $29^{\text {th }}$ June 2019 RECEIVED in revised form $27^{\text {th }}$ August 2019 ACCEPTED in final form $31^{\text {st }}$ August 2019

\begin{abstract}
Salix spp. cortex is a bark extract from the common plant willow including $S$. purpurea L., S. daphnoides Vill. and S. fragilis L, traditionally used in human medicine (i.e. for acetylsalicylic acid usually called aspirin). It is an approved basic substance with fungicidal properties under agricultural EU pesticide regulation (Regulation (EC) no 1107/2009) since 2015. Currently, its approved uses are for arboriculture and viticulture. An initial use extension to allow nurseries to use it as a plant growth regulator is being evaluated by the EU regulatory assessment organisation. Willow water helps cuttings to root, due to its indole butyric acid content, which is a growth hormone (plant growth regulator) in the auxin family and generally chemically synthesized for this purpose. Recently, fungicide usages for the vegetable and fruit market (tomatoes, berries and kiwis) have been submitted to the EU Commission for evaluation. Initial main field trials to demonstrate its plant protection properties were coordinated in France by the 4P project "Protection des Plantes Par les Plantes" (Plant Protection by Plants) between 2010 and 2013 but additional field trials were collected. We detail in this study the results obtained and all the uses of this extract as a plant protection product, including inducing rooting. In addition, we describe the full approval processes for the basic substance Salix spp. cortex and these extensions of use, covered by the Article 23 of the plant protection regulation in EU.
\end{abstract}

Keywords: Salix cortex, fungicide, plant growth regulator, biorational, basic substance

\section{Introduction}

Willows (Salix spp.) include trees and shrubs of the family Salicaceae. The genius Salix includes 450 species, the family Salicacea much more, distributed around the world and usually colonises riparian habitats including wetlands and riverbanks, with some of the best known species the white willow (Salix alba) (Argus, 1997).

Willow extracts have been used for thousands of years in medicine to relieve various aches. The bark is traditionally used for muscular and osteoarthritic rheumatism with inflammation and pain, influenza, respiratory catarrh, gouty arthritis, ankylosing spondylitis, and specifically for rheumatoid arthritis and other systemic conditions characterized by inflammation responses (EMA, 2017). It has long been used in Europe 
and China for the treatment of these conditions. Assyrians and Egyptians were already aware of the analgesic effects of a willow leaves decoction (extract) to relieve joint pains. At the beginning of the $19^{\text {th }}$ century, salicin (an alcoholic $\beta$-glucoside of salicylic acid) was extracted from the willow bark and purified: the active extract, called salicin, was isolated in its crystalline form in 1828 by Leroux, a French pharmacist, and Piria, an Italian chemist, who managed to separate the acid in its pure state (Levesque and Lafont, 2000). Later, a chemist named Gerhardt succeeded in synthesizing acetylsalicylic acid from salicin, which later became the active substance of a drug: aspirin (Fuster et al., 2011).

Outside of the medicinal environment, considering its properties, several people have tried to use it as plant protection product since plant diseases are an important struggle in crop production (Banik, 2016). Effectiveness in vineyard protection against downy mildew was previously shown (Kast, 2002). Antifungal properties were also described to explain this potential efficiency (Arif et al., 2011). It is for this field trial purpose that the Organic Food and Farming Institute (ITAB) conducted the " $4 \mathrm{P}$ " experimental program. This work was undertaken in order to be able to cope with probable reduction that will be required for the use of copper per hectare and per year during ongoing renewal procedures at general EU pesticide regulation. The " $4 P$ " program was designated to test plant extracts as complementary solutions to overcome the actual ongoing reduction of copper quantities allowed.

Later, ITAB worked on the approval of the Salix spp. cortex as plant protection means by the European Union. The application proceeded as "basic substance" in agriculture as biorational for all Europe (Marchand, 2016).

The adoption of the new plant protection products regulation (EC) No 1107/2009 made the approval of plant extracts possible as "basic substances" at the EU level in accordance with Article 23. Basic substances are active substances which are not normally used as plant protection products, but which can be useful for the protection of plants but whose economic value for the approval of such substances may be limited. At present, 20 basic substances that have been identified as having neither immediate nor delayed harmful effects on human and animal health nor unacceptable effects on the environment are approved. In accordance with the criteria of Article 2, basic substances are granted without maximum residue limits and are likely to be included in Annex II of the Regulation (EC) 889/2008. These substances are all usable for the protection of conventional crops and some in organic production also (Marchand, 2015, 2016, 2017a).

The application file for Salix cortex substance was partly based on the results of the " $4 P$ " research program (Marchand et al., 2014). The " $4 P$ " project involved analyses of diverse plant content including white willow (Salix alba) (Andreu, 2018). This project focused on the search for alternatives to the chemical pesticides use based on the evaluation of herbal preparations for the purpose of protecting plants against bioaggressors regarding their "fungicidal" potential. Salix infusion contains also various inactive compounds, together with the potential active components, like salicylic acid. Several studies have also shown that salicylic acid own antifungal activity (da Rocha Neto et al., 2015; Tosun et al., 2003). Indole 3-butyric acid (IBA) is also present in Salix bark extract, which is a phyto-hormone that promotes and accelerates root formation (USEPA, 1992). ITAB is currently working on extending the uses of this basic substance.

Willow bark has long been used as a fungicidal plant protection extract. The recipe (infusing the bark in water at a temperature below $80^{\circ} \mathrm{C}$ ) is included in the approval case file and previously published (Marchand, 2016). The actual claimed uses are limited to grapevine against Plasmopara viticola (downy mildews) and Erysiphe necator (powdery mildews), in arboriculture for apple trees targeted toward foliar fungi like scab disease Venturia inaequalis and powdery mildews Podosphaera leucotricha, and for peach trees against foliar fungi like Taphrina deformans.

Interest for this substance as natural resource for plant protection (Maiti, 2016) is multiple: it is useful for plant protection by acting as an elicitor of the resistance and defence mechanisms in the plants (Dempsey, 2017); moreover direct antifungal properties were proved through field trials (Gilliver, 1947). This extract is environmentally friendly due to the fact that the supposedly active molecules are not exhibiting biocides properties as in line for human consumption (EMEA, 2009). Willow infusion inhibits the germination and the spread of fungal diseases without really killing the fungi as expected for chemical pesticide. Botrytis cinerea and Penicillium expansum are also important plant pathogens for these crops, mainly contaminating postharvest fruits. Salix cortex has been shown to have antifungal activity against these two fungi (Andreu et al., 2018; Hussain et al., 2011) with the same recipe used in arboriculture and viticulture (Marchand, 2016).

\section{Materials and Methods}

\subsection{Composition of the extract}

Full phenolic composition of white willow (Salix alba) extract was described during the " $4 P$ " project (Andreu, 2018). Indole 3 -butyric acid (IBA), not considered in the " $4 P$ " project is also present in Salix bark extract (USEPA, 1992).

\subsection{Willow extract recipe for nursery uses}

Mode of preparation is consisting in hot water infusion at 80 ${ }^{\circ} \mathrm{C}$ then dilution. In 30 litres of natural or rain water brought to simmering in a stainless steel tank with cover, at $80{ }^{\circ} \mathrm{C}$ infuse $200 \mathrm{~g}$ of the aerial part of Salix spp. cortex dry plant for 2 hours. After cooling down, and filtration with stainless steel sieve, adjust $\mathrm{pH}$ to 6.2 and proceeds the dilution by 3 (with natural or rain cold water). Final \% of total eq. salicin (w/v) in 
the mother infusion is $1\left(\mathrm{~g}^{-1}\right)$. Final $\%$ of total eq. salicin $(\mathrm{w} / \mathrm{v})$ in the preparation is therefore $1 / 3\left(\mathrm{~g}^{-1}\right)$.

The other recipe for fungicide uses is described (Marchand, 2016) or accessible in the corresponding Salix cortex Review Report in EU pesticide database (DG Health and Food Safety, 2019).

\subsection{In vitro action and field trials during the " $4 P$ " project}

The " $4 P$ " project was also dedicated to experimental usefulness trials. Experiments suggest an optimal dosage of 0.5 $\mathrm{mg} \mathrm{l}^{-1}$ for this extract. Investigations were conducted in order to show the range of activities of plant protection properties against bio-aggressors in arboriculture, market gardening and viticulture. This " $4 P$ " project focused on the fungicidal properties together with the eco-toxicity characterisation of these extracts (i.e. studies versus non target organisms). The agronomic efficacy studies are based on field experiments carried out on a plots network and the eco-toxicity of the extract was evaluated in laboratory. However, the results presented here are only part of the " $4 P$ " program dedicated to willow bark extracts.

\subsection{In vitro effects of Salix cortex infusion on grapevine and orchard phytopathogen}

In vitro tests were carried out on grapevine downy mildew (Plasmopara viticola): three types of tests were executed on loose leaves, from Aquitaine vineyard: anti-germinative, curative and preventive. Inoculation protocol were conducted as follow: the pathogen (Plasmopara viticola) population used for the 2012 trials comes from late season (Sept, 2011) leaf sporulation samples from Château Dillon plots. Whole leaves were frozen and stored in bags. Seasonal mildew samples have completed this stock. The sporocysts of $P$. viticola are leached from the leaf sporulation with distilled water and a brush and accumulated in a beaker placed in ice. The density of the inoculum is controlled with a Malassez cell from a sample. The inoculum must reach a density of about $10 \times 105$ sporocysts / $\mathrm{ml}$. The detached vine leaves (vegetal material for inoculation) used in the in vitro tests came from the parcels of Château Dillon and come from Merlot Noir grape varieties. Inoculation was done by drop at the rate of one drop of $15 \mu$ l of spore solution for one disc. After inoculation, the disks were placed in the dark for a minimum period of 5 hours, and then the drops of inoculum are aspirated using a pipette (Marchand, 2014). The leaves were then kept in the culture chamber. In general the first sporulation appear 5 days after inoculation. The biological activities of plant extracts were also tested in the laboratory for their antifungal activity on different species of phytopathogenic fungi (Penicillium expansum and Botrytis cinerea) with identical protocol.

\subsection{Field trial protocols}

The starting postulates were adopted for all trials: the limitation of the total quantities of copper metal was set up to a maximum of $6 \mathrm{~kg} \mathrm{ha}^{-1}$ year $^{-1}$ as foreseen by the current
EU Regulation in Organic Production, and of the maximum number of treatments was limited to 10.

Field trials were done according to Vegephyl-Anses C.E.B. (Commission des Essais Biologiques) methods (No. 7, No. 14, No. 22, No. 33 and for No. 53 Plasmopara viticola, Venturia inaequalis, Erysiphe necator, Taphrina deformans and Guignardia bidwellii respectively) (Vegephyl, 2018).

2.6. In campo activity of Salix cortex infusion on grapevine and orchards phytopathogen

\subsubsection{In vineyards}

\subsubsection{P. viticola}

In vineyards, work was carried out over three years against the grapevine downy mildew pathogen $(P$. viticola), with testing carried out in association with a low dose of copper, in comparison to a regional copper reference (400 to $600 \mathrm{~g}$ of eq. copper metal per hectare), an untreated control and low-dose copper modality (150 g copper metal per hectare). For each modality, the frequency and the intensity of late downy mildew on the leaves and fruit clusters were measured. Secondary observations were also monitored on blackrot (Guignardia bidwellii).

Postulates adopted after meeting with grapevine responsible for all tests: limitation of the total quantities of copper metal to $6 \mathrm{~kg} \mathrm{ha}^{-1}$ year $^{-1}$ as foreseen by the current EU Regulation in organic farming; limitation to 10 of the number of treatments. This number may be lower depending on climatic conditions and disease pressure of the year. We will simply make sure, for a given test, to do the same number of treatments in all the modalities so that the comparisons between the modalities can be possible. Terms of treatments are described in Table 1 .

\begin{tabular}{|c|c|c|c|c|}
\hline $\begin{array}{l}\text { Modal- } \\
\text { ity }\end{array}$ & 0 & 1 & 2 & 3 \\
\hline $\begin{array}{l}\text { Depic- } \\
\text { tion }\end{array}$ & $\begin{array}{l}\mathrm{Con}- \\
\text { trol }\end{array}$ & $\begin{array}{l}\text { Regional ref- } \\
\text { erence } f\end{array}$ & $\begin{array}{l}\text { "low copper } \\
\text { only" \$ }\end{array}$ & $\begin{array}{l}\text { " I o w } \\
\text { copper } \\
+ \text { infu- } \\
\text { sion" }\end{array}$ \\
\hline \multirow[t]{2}{*}{$\begin{array}{l}\text { Descrip- } \\
\text { tion }\end{array}$} & $\begin{array}{l}\text { U n - } \\
\text { treat- } \\
\text { ed }\end{array}$ & $\begin{array}{l}\text { between } 400 \\
\text { and } 600 \mathrm{~g} / \\
\text { treatment }\end{array}$ & $\begin{array}{l}250 \mathrm{~g} / \text { treat- } \\
\text { ment under } \\
\text { controlled } \\
\text { conditions }\end{array}$ & $\begin{array}{l}\text { dose de- } \\
\text { fined in } \\
\text { modal- } \\
\text { ity } 1 \text { in }\end{array}$ \\
\hline & & & $\begin{array}{l}150 \mathrm{~g} / \text { treat- } \\
\text { ment under } \\
\text { natural field } \\
\text { conditions }\end{array}$ & $\begin{array}{l}\text { associa- } \\
\text { tion with } \\
\text { willow } \\
\text { leaves } \\
\text { infusion }\end{array}$ \\
\hline
\end{tabular}

* Quantities of "copper" are considered as mass of copper metal; $f$ Doses of copper commonly used in the region; $\$$ In this modality copper is used in this modality alone and at low dose 
The product chosen for all the tests and modalities is Kocide opt ${ }^{\circledR}$ copper hydroxide (Dupont company) because of its formulation in dispersible granules and of its recent homologation at $750 \mathrm{~g} \mathrm{ha}^{-1}$ of copper metal is $2500 \mathrm{~g}$ of product ha ${ }^{-1}$. Note that for a given modality we work at constant dose of copper/treatment throughout the season.

Basic plots trials: 5 grapevine feet minimum as described in C.E.B. protocols (Vegephyl, 2018): feet \# 1 and \# 5 are out of the test and feet \# 2, 3, 4 are monitored and misted. 4 repetitions per modality were observed with renewal of treatments every 8 to 12 days after each fogging; every ten days in regional reference (Table 1. $f$ ) in the absence of rain; after a rain (the next day) if it is greater than or equal to 20 $\mathrm{mm}$, but within the limit of the expected rate of 8 to 12 days.

Notations were done with three counts minimum: at inflorescence / fruit set leaves and bunches (grey rot); at the beginning of veraison leaves and clusters (brown rot) and at harvesting leaves only (or defoliation). Notations must comply with the C.E.B. protocols (Vegephyl, 2018), and relate to intensity and frequency (leaves and clusters). In all cases the counts are carried out either on all the clusters +100 leaves, or on 100 clusters and 100 leaves according to the size of the elementary parcel, avoiding the edge vines, by alternating the positions of notation and while maintaining the same observer throughout the same repetition. Antipowdery mildew: treatment with Thiovit $^{\circledR}$ or Microthiol ${ }^{\circledR}$ if necessary to provide effective protection against powdery mildew. Anti-powdery mildew treatments were decoupled from anti-mildew treatments; the same on all modalities including cookies, and with the same commercial product throughout the season. Volume of mixture to spray on crops is 120 to $200 \mathrm{I} \mathrm{ha}^{-1}$ with a pneumatic backpack sprayer to be adapted if necessary with the vegetation stage. It was ensure that the presence of a weather station or the possibility of rainfall recordings was available within a radius of $5 \mathrm{~km}$ around the test.

\subsubsection{E. necator}

The starting postulates adopted for all tests were: no limitation of the quantities of sulphur and no limitation on the number of total treatments (however, make the same number of treatments for all modalities). Terms/ modalities are described in Table 2.

The product selected for all tests and modalities is Microthiol Special Disperss ${ }^{\circledR}$ (Cerexagri Company). Basic plots with 5 feet minimum defined by C.E.B. protocols (Vegephyl, 2018): feet\# 1 and \# 5 are out of the test and feet \# 2, 3, 4 are noted and misted. 4 repetitions per modality were collected and delays between treatments were from 8 to 12 days. Notations were collected with two counts minimum (with the possibility to make three) and with counting only on clusters but possible to make foliage logs when it is obvious. In all cases the counts are carried out either on all the clusters +100 leaves, or on 100 clusters according to the size of the elementary

\begin{tabular}{|c|c|c|c|c|}
\hline Modality & 0 & 1 & 2 & 3 \\
\hline $\begin{array}{l}\text { De p i c- } \\
\text { tion }\end{array}$ & $\begin{array}{l}\text { Con- } \\
\text { trol }\end{array}$ & $\begin{array}{l}\text { Regional } \\
\text { reference } \mathrm{f}\end{array}$ & $\begin{array}{l}\text { "low sulphur } \\
\text { alone " \$ }\end{array}$ & $\begin{array}{l}\text { "low sul- } \\
\text { phur + in- } \\
\text { fusion" }\end{array}$ \\
\hline $\begin{array}{l}\text { Descrip- } \\
\text { tion }\end{array}$ & $\begin{array}{l}\text { Un- } \\
\text { treat- } \\
\text { ed }\end{array}$ & $\begin{array}{l}5000 \mathrm{~g} / \\
\text { treatment }\end{array}$ & $\begin{array}{l}1600 \mathrm{~g} / \\
\text { treatment } \\
\text { for Burgun- } \\
\mathrm{dy} \\
2000 \mathrm{~g} \text { for } \\
\text { regions with } \\
\text { high pres- } \\
\text { sures }\end{array}$ & $\begin{array}{l}\text { dose de- } \\
\text { fined in } \\
\text { modality } 1 \\
\text { in associa- } \\
\text { tion with } \\
\text { w ill o w } \\
\text { leaves in- } \\
\text { fusion }\end{array}$ \\
\hline
\end{tabular}

* Quantities of "sulphur" are considered as mass of pure sulphur; $f$ Doses of sulphur commonly used in the region; $\$$ In this modality sulphur is used in this modality alone and at low dose

parcel, avoiding the edge vines, by alternating the positions of notation and by keeping the same note-takers throughout the same repetition. Anti-mildew cover treatment if necessary was done with a copper hydroxide or a copper sulphate so as to provide effective protection against late blight, within the limits of $6 \mathrm{~kg} \mathrm{ha}^{-1}$ year ${ }^{-1}$ provided by the organic farming regulation. Anti-mildew treatments were decoupled from anti-powdery mildew treatments; make them identical on all modalities including controls, and with the same commercial product throughout the season. Volume of slurry to spray was defined from 120 to $200 \mathrm{I} \mathrm{ha}^{-1}$ to be adapted if necessary with the stage of vegetation. Ensure the presence of a weather station or the possibility of rainfall readings within a radius of $5 \mathrm{~km}$ around the test.

\subsubsection{In orchards}

\subsubsection{T. deformans}

In arboriculture (peach trees): the objective was the protection of fruit trees and the search for alternatives to the use of sulphur and copper compounds against peach leaf curl ( $T$. deformans). For peach trees, the experimentations were performed in an organic peach orchard, with the Spring Lady variety: an early and sensitive to the leaf curl pathogen. The trial plot was converted to organic farming since 2010. The orchard has a leaf curl inoculum occurrence from medium to high (in 2010). The plant extracts were sprayed in addition to the producer's treatments. The producer's pathway for fungal diseases consists of a mixture of sulphur, potassium bicarbonate, terpene alcohol (heliosol ${ }^{\circledR}$ ) and leaf fertilizer (UFAB Biotham ${ }^{\circledR}$ ), including lithothamne, silica and copper. These treatments were applied on all trees. The schedule of treatments and observations was conducted as such: two treatments were carried out ( 1 treatment / week, 03 and 9 July) in prevention to the development of leaf curl 
on fruit. On the other hand, the producer has carried out several fungicide treatments since the beginning of the year, including two sulphur-based treatments, 15 days before the first treatment and the day after the second treatment, respectively. Harvesting (16/07/12) was carried out one week after the last treatment and 2 days before the first harvest of the producer. The observations correspond to: estimate of the frequency of tree fruits: count of the number of fruits per 100 fruits observed at human height (because hail 8 days before harvest and top fruits damaged) the day before harvest and estimation of the frequency of the attack of leaf curl on a sample of 12 healthy fruits and without wounds during the sampling, corresponding to 60 fruits by modality and preserved at ambient temperature. Frequency is the number of fruits affected compare to the total number of fruits.

\subsubsection{V. inaequalis}

Choice of varieties was focused on apple trees with very strong sensitivity variety against scab: Jugala. A true control (no fungicide treatment) was implemented on the orchard according to an included scheme. Fisher type block device with 4 repetitions was fooled with orchard size of $50 \times 25$ $\mathrm{m}^{2}$; experimental elementary plots consisted of 3 trees. The reference was the included control and five other modalities were studied. All treatments were done with a predictive positioning with a pace of 7 days maximum. A renewal of protection was realized when crossing the $20 \mathrm{~mm}$ threshold precipitation. Predictable period of primary contaminations was 25 March-30 June whereas effective period of primary contaminations: 27 April-28 June. The treatments were made using a STIHL SR400 atomizer. The volume of slurry was 500 I ha-1. Other orchard maintenance treatments like fungicides applied on the plot were suspended throughout the test period on the experimental ranks and guard rows. Several ratings were performed on each modality. The first was done from the first exit stains from the first contaminations. Then every week after the first scoring up the end of primary contaminations, a follow-up of the evolution of secondary contaminations was pursued at the same frequency. A last rating has occurred when the crop has finished. In view of the main protection program for apple scab, the periods of notations are based on observations made for scab. The first one after the exit first spots from the first contaminations (before flower) then every week after then first rating up to the end of contaminations and the program of field observations, was mainly to observe the fruit decays. The ratings involved the observation of 210 leaves on the 3 trees of each parcel total of 840 sheets for each modality. An equitable distribution of different leaf areas was respected according to the following schema: leafy stage (Tree 1 Tree 2 Tree 3); top 2 shoots of 10 leaves 2 shoots of 10 leaves 2 shoots of 10 leaves; medium 3 shoots of 10 leaves 3 shoots of 10 leaves 3 shoots of 10 leaves; low 2 shoots of 10 leaves 2 shoots of 10 leaves 2 shoots of 10 leaves. The leaves were divided into two classes as follows: 0 : leaves free from scab /1: leaves having at least one scab spot. On fruits, the ratings involved all the fruits observable on the 3 trees of each parcel. The fruits were classified in 2 categories: 0 : fruit free of blemishes/1: fruits having at least one scab spot.

\subsection{Ecotoxicity assessment}

\subsubsection{On bees}

SupAgro Montpellier laboratory has performed toxicity tests of willow bark and willow leaf extracts on bees (Apis mellifera), by both feeding and contact methods. The protocols used for the oral toxicity test are carried out according to C.E.B.-Anses methods No. 230 (Vegephyl, 2018). Each test is composed of the following modalities:

- control treatment carried out with sugar distilled water $\left(500 \mathrm{~g} \mathrm{l}^{-1}\right)$,

- treatment by plant extracts, bark and willow leaves at 5 concentrations (regular application rate $\mathrm{D}$, and dilutions: $\mathrm{D} / 10$, $\mathrm{D} / 5,2 \mathrm{D} / 5$ and $3 \mathrm{D} / 5$ ).

The concentration of the preparation to be tested represented $10 \%$ of the final volume of feeding syrup.

In order to evaluate the deleterious effects of the substances by contact, a tissue with a surface area of $100 \mathrm{~cm}^{2}$ was deposited in the boxes of contention; the tissue being sprayed by the substance under controlled conditions using a Potter tower (Potter, 1952). The solutions were applied in such a way that $1.5 \mathrm{mg}+/-0.2 \mathrm{mg}$ of the substance was deposited per $\mathrm{cm}^{2}$ of tissue.

Each test exhibited the following modalities:

- the control treatment was performed with distilled water.

- the treatment with the bark extracts at 5 concentrations (see above).

\subsubsection{On aquatic organisms}

Finally, a toxicological study of the preparations, not previously published was carried out by the University of Perpignan on aquatic organisms, two classical models were used: the brine shrimp artemia (Artemia salina) and the water flea daphnia (Daphnia pulex) using the OECD 202 protocol (OECD, 1984).

\section{Results and Discussion}

\subsection{Salix cortex as anti-germinative substance against fungi}

The analyses of the willow preparation only showed effective result against on the germination of $P$. viticola. For the characterisation of the inhibitory effects on the various peach and vine pathogenic fungi, the willow bark extract has an interesting activity, which is found to be more active than the willow leaf extract (Marchand, 2014).

Salix cortex as a fungicidal means on grapevine, peach and apple trees

\section{Salix cortex as a fungicidal on apple trees}

The untreated control apple trees in the field experimental 
conditions exhibit a $V$. inaequalis attack percentage of about $11 \%$ and are distinguishable from other treatment modalities. Treated modalities are labelled "salix 1 to 4 " are corresponding to different trials with willow infusion. Light fungicidal effect of the Salix extract was measured on apple trees (Figure 1a.) with only between 5 and $6.5 \%$ of the leaves surface infested with apple scab disease (Figure 1b.). Trees treated with willow infusion show a reduction of more than half of the $V$. inaequalis attacks as compared to the untreated controls. Light fungicidal effect was also measured on specked shoots (Figure 1c.) compare to full and reduced copper doses treatments.

\subsection{Salix cortex as a fungicidal means on grapevine}

Concerning the vineyards, the trials show a small fungicidal effect for willow herbal tea/Salix cortex extract treatments on grapes against $P$. viticola, the grapevine downy mildew agent (Figure 3a). Complete mode of action of the Salix cortex extract is not fully understood, but it is known that this willow

a) Effect on apple

$V$. inaequalis \% on fruit surface

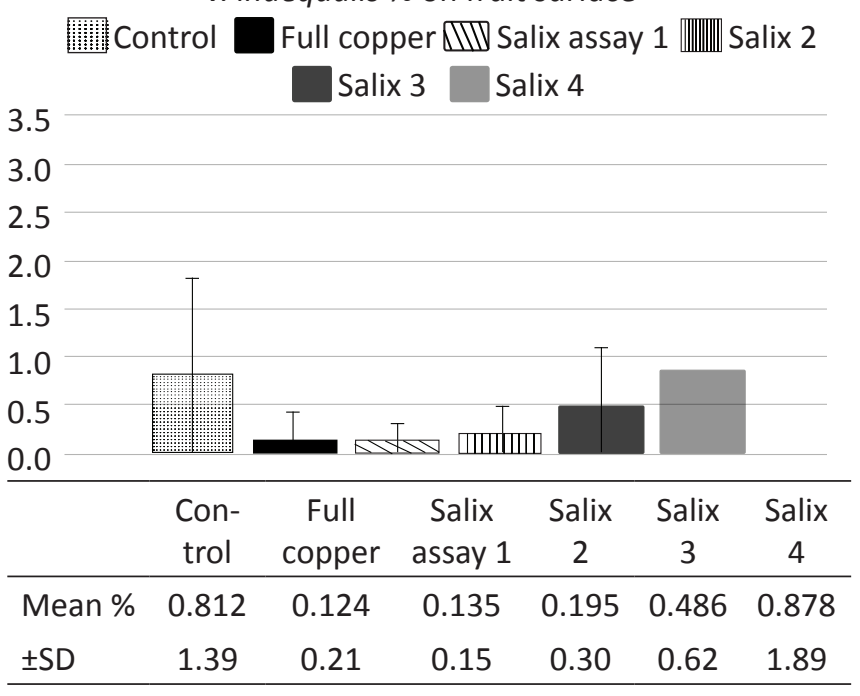

b) Effect on leaves

V. inaequalis $\%$ on leaf surface
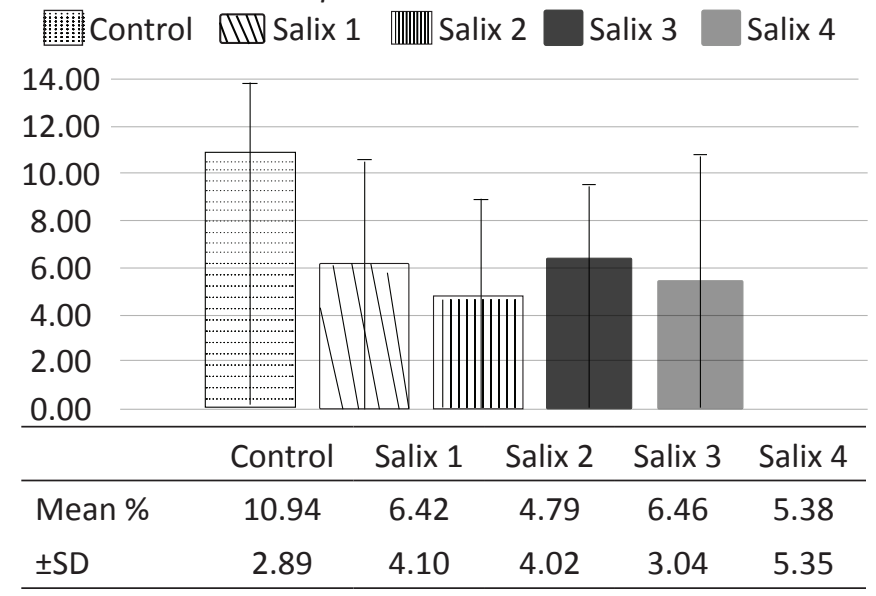

c) Effect on shoots

$V$. inaequalis \% on speckled shoots

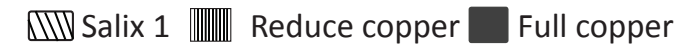

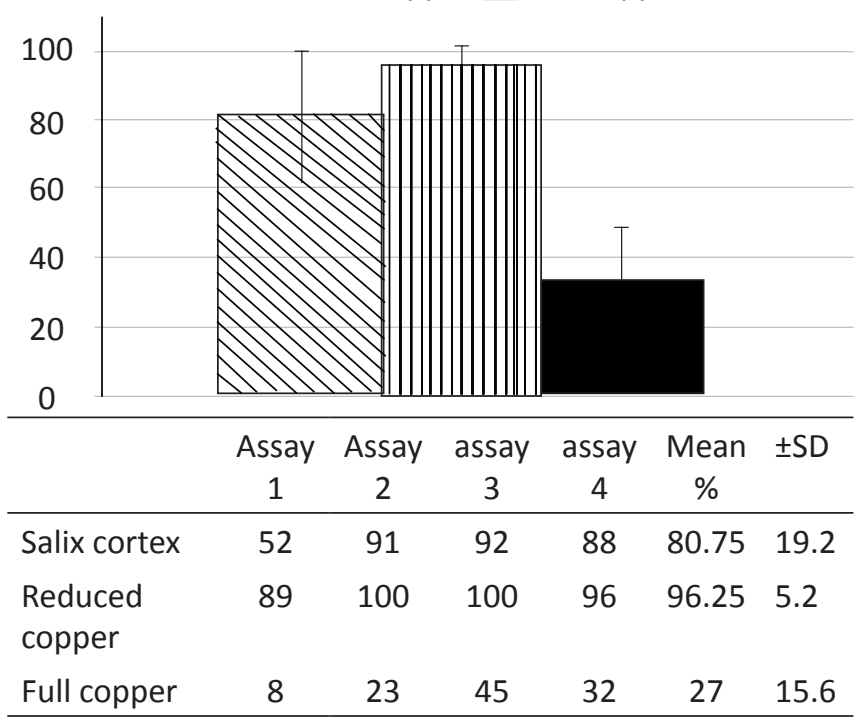

Figure 1: Fungicidal efficacy of Salix cortex against apple scab disease $V$. inaequalis a) on the fruits $b$ ) on the leaves and $c$ ) on the shoots

extract exhibit antigerminative property as Equisetum extract during the "4P" CASDAR project (Marchand, 2014). Main observations of the fungicidal resulting effect were managed on downy mildew expansion since the effect was reported, but secondary observation on blackrot were also achieved and reported on Figure 2.

\subsubsection{Salix cortex as a fungicidal extract on peach trees}

Effect on Monilia contaminations was recorded in orchards. Slight fongistatic effect is observed regarding average result but in some cases the contamination may be reduced by a factor of 2 . These promising results should generate further research and trials since literature show some potential (Alfredsen, 2008) Figure 3.

\subsection{Willow extract is nontoxic to bees and aquatic organisms}

Regarding the toxicity by feeding, the extract of Salix cortex has no observable lethal or acute effect on bees for the five concentrations tested, in fact, the induced mortality did not reach $10 \%$ after $96 \mathrm{~h}$. For contact toxicity tests after $96 \mathrm{~h}$, the deaths observed were lower by contact than by ingestion for all the extracts tested. The treatment with Salix cortex did not induce a clear excess mortality among the bees for all the concentrations tested as reported in Figure 4.

For aquatic organisms, the effective concentration of willow (whether leaf or bark) is much higher than that of references cited in literature, so the Willow extracts were also less toxic (Table 3).

\subsection{Salix as plant growth regulator}

The willow bark extract strongly stimulated the growth of 
roots from shoots. Indeed, the willow is a plant that is easy to grow from cuttings, probably due to its high indole-3-butyric acid (IBA) content. IBA is a plant hormone of the auxin family, which is involved in many developmental processes including lateral roots production (Bertoni, 2011). Many studies show the effect of IBA on cuttings (Tajbakhsh, 2009; Qaddoury, 2003), some of which are known as being difficult to root, such as kiwi (Alam et al., 2007). Therefore, we propose a use of willow water in the nursery to help cuttings, according to the recipe in material and methods chapter (2.2).

\subsection{Salix a fungicide for kiwi, tomatoes and berries}

These trials were undertaken in order to be able to cope with ongoing reduction of chemical pesticides. Salix extract known previously for fungistatic effects on diverse crops was tested on new production, especially crops selected to be eaten as raw fruits like kiwi, tomatoes and berries. Results transferred in a regulatory extension of uses are not shown in this paper.

a) Effect on grapes in \%

P. viticola/G. bidwellii \% on grapes

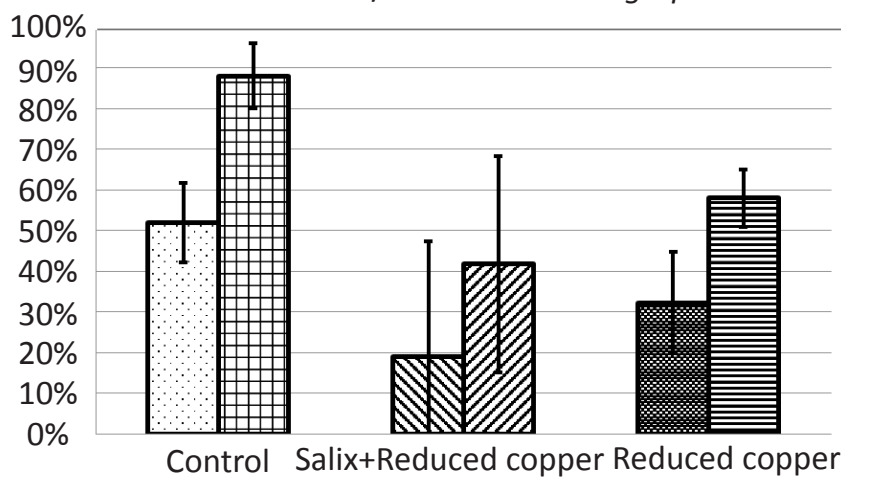

\begin{tabular}{|c|c|c|c|c|c|c|}
\hline \multicolumn{7}{|l|}{ P. viticola } \\
\hline & assay & assay & assay & assay & Mean & $\pm S D$ \\
\hline & 1 & 2 & 3 & 4 & $\%$ & \\
\hline $\begin{array}{l}\text { Salix +Re- } \\
\text { duced cop- } \\
\text { per }\end{array}$ & 20 & 32 & 12 & 12 & 19.0 & 9.5 \\
\hline $\begin{array}{l}\text { Re d u ce d } \\
\text { copper }\end{array}$ & 44 & 9 & 24 & 52 & 32.3 & 19.5 \\
\hline Control & 36 & 72 & 20 & 80 & 52.0 & 28.7 \\
\hline \multicolumn{7}{|l|}{ G. bidwellii } \\
\hline & assay & assay & assay & assay & Mean & $\pm S D$ \\
\hline & 1 & 2 & 3 & 4 & $\%$ & \\
\hline $\begin{array}{l}\text { Salix+ re- } \\
\text { duced cop- } \\
\text { per }\end{array}$ & 0 & 59 & 48 & 60 & 41.75 & 28.0 \\
\hline $\begin{array}{l}\text { Re d u ce d } \\
\text { copper }\end{array}$ & 48 & 56 & 76 & 52 & 58 & 5.0 \\
\hline Control & 80 & 80 & 100 & 92 & 88 & 10.0 \\
\hline
\end{tabular}

\subsection{From general regulation point of view}

3.6.1. Salix spp. cortex as a basic substance for plant protection.

Initial Basic Substance Application (BSA) for Salix spp. cortex was constituted following the corresponding Guideline (DG Health and Food Safety, 2014) and our previous work (Marchand, 2015). We were aiming for the approbation of Salix spp. cortex by the European Union as "basic substance", (Marchand, 2017c) according to provisions of article 23 laid down by EC regulation 1107/2009 on placing plant protection products on the market. Salix spp. cortex was thereby submitted as a basic substance application (BSA) and was declared eligible in 2015.

After the eligibility and the assessment by Europe, the European Food Safety Authority (EFSA) issued a negative opinion on the "Salix spp. cortex" dossier. Indeed, Salix spp. cortex would not be a basic substance because it would be a formulated product, given that it is extracted at $80^{\circ} \mathrm{C}$ and the

b) Effect on leaves in \%

\section{P. viticola/G. bidwellii \% on leaves}

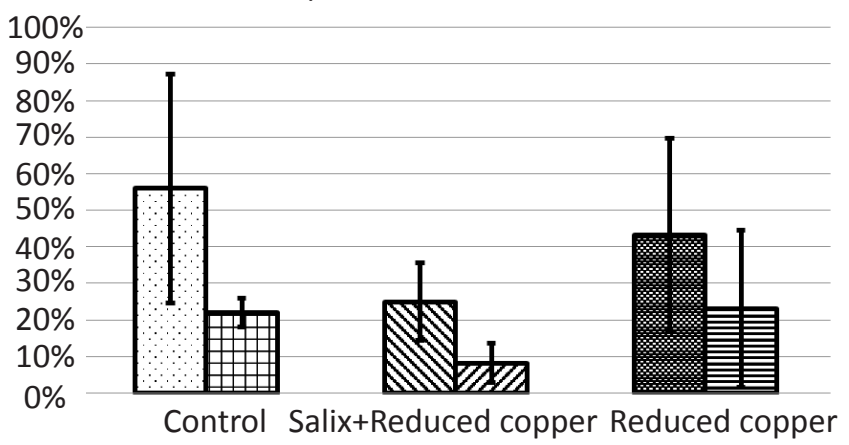

\begin{tabular}{|c|c|c|c|c|c|c|}
\hline \multicolumn{7}{|l|}{ P. viticola } \\
\hline & assay & assay & assay & assay & Mean & $\pm S D$ \\
\hline & 1 & 2 & 3 & 4 & $\%$ & \\
\hline $\begin{array}{l}\text { Salix +Re- } \\
\text { duced cop- } \\
\text { per }\end{array}$ & 20 & 56 & 16 & 8 & 25.0 & 10.5 \\
\hline $\begin{array}{l}\text { Re d u c e d } \\
\text { copper }\end{array}$ & 80 & 17 & 40 & 36 & 43.3 & 26.5 \\
\hline Control & 40 & 64 & 24 & 96 & 56.0 & 31.3 \\
\hline \multicolumn{7}{|l|}{ G. bidwellii } \\
\hline & assay & assay & assay & assay & Mean & $\pm S D$ \\
\hline & 1 & 2 & 3 & 4 & $\%$ & \\
\hline $\begin{array}{l}\text { Salix+ re- } \\
\text { duced cop- } \\
\text { per }\end{array}$ & 5.0 & 8.0 & 16 & 4.0 & 8.3 & 5.4 \\
\hline $\begin{array}{l}\text { R e d u c e d } \\
\text { copper }\end{array}$ & 52 & 0.0 & 20 & 20 & 23.0 & 21.5 \\
\hline Control & 20 & 20 & 24 & 24 & 22.0 & 3.8 \\
\hline
\end{tabular}

Figure 2: Continue... 
c) Effect on grapes in intensity

P. viticola/G. bidwellii \% intensity on grapes

\begin{tabular}{|c|c|c|c|c|c|c|}
\hline \multicolumn{7}{|l|}{$100 \%$} \\
\hline $90 \%$ & & & & & & \\
\hline $80 \%$ & & & & & & \\
\hline $70 \%$ & & & & & & \\
\hline $60 \%$ & & & & & & \\
\hline $50 \%$ & & & & & & \\
\hline $40 \%$ & I & & & & & \\
\hline $30 \%$ & 且 & & & & & \\
\hline $20 \%$ & 曲 & & & & & \\
\hline $10 \%$ & 册 & & $D$ & & & \\
\hline $0 \%$ & ontrol & Salix+Re & duced $c$ & opper & Reduced & copper \\
\hline P. viticola & & & & & & \\
\hline & assay & assay & assay & assay & Mean & $\pm S D$ \\
\hline & 1 & 2 & 3 & 4 & $\%$ & \\
\hline $\begin{array}{l}\text { Salix +Re- } \\
\text { duced cop- } \\
\text { per }\end{array}$ & 1 & 6.4 & 1.1 & 0.8 & 2.3 & 2.7 \\
\hline $\begin{array}{l}\text { Reduced } \\
\text { copper }\end{array}$ & 9.2 & 1.0 & 4.6 & 10.4 & 6.3 & 4.3 \\
\hline Control & 5 & 17.3 & 2.5 & 14 & 9.7 & 7.1 \\
\hline G. bidwellii & & & & & & \\
\hline & assay & assay & assay & assay & Mean & $\pm S D$ \\
\hline & 1 & 2 & 3 & 4 & $\%$ & \\
\hline $\begin{array}{l}\text { Salix+ re- } \\
\text { duced cop- } \\
\text { per }\end{array}$ & 0 & 10.9 & 5.85 & 4.1 & 5.2 & 4.5 \\
\hline $\begin{array}{l}\text { Reduced } \\
\text { copper }\end{array}$ & 7.8 & 8.6 & 28.5 & 6.4 & 12.8 & 10.5 \\
\hline Control & 21.9 & 23.1 & 36.6 & 43.0 & 31.1 & 10.3 \\
\hline
\end{tabular}

Figure 2: Effect of Salix cortex application against Plasmopara viticola (downy mildew) a) on the grapes b) on the leaves grapevine. Secondary observations were done on Guignardia bidwellii (black rot)

$\mathrm{pH}$ is adjusted. In addition, the assessment of non-alimentary risks is inconclusive and information is lacking about the fate and behaviour of the substance in the environment (EFSA, 2014).

However, the Commission approves Salix spp. cortex as a basic substance in accordance with Article 23 of Regulation (EC) No 1107/2009, stating that Salix spp. cortex is a part of plant found throughout the environment and the additional exposure of humans, animals and the environment is negligible compared to the expected exposure in an ordinary natural context (EU, 2015). Voting at standing Committee on Plants, Animal, Food and Feed (PAFF committee) was done according to the EU official vote procedure (Marchand, 2015).
Effect on Brown rot at harvesting time

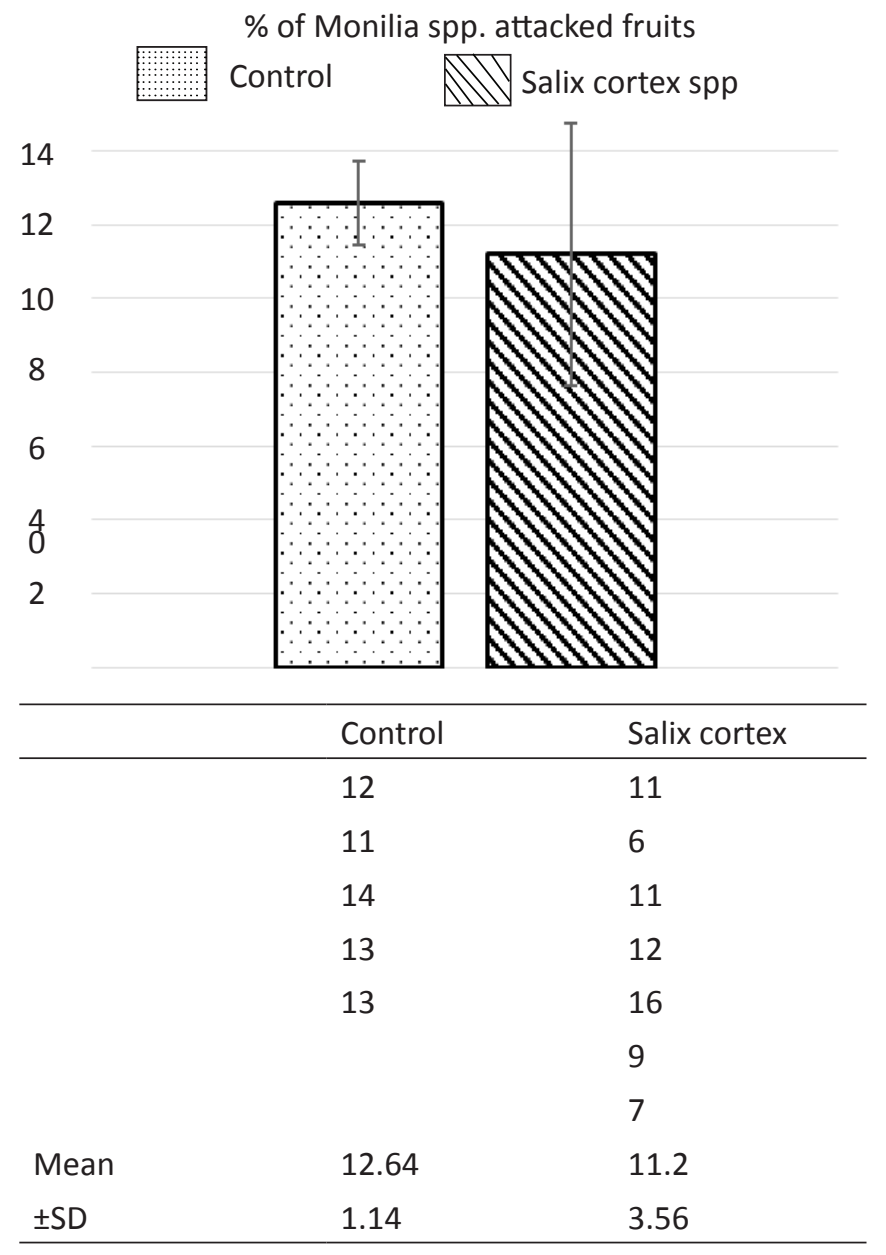

Figure 3: Fungicidal usefulness of Salix cortex for peach tree protection

Table 3: Aquatic toxicity of willow extracts. Effective concentration (EC50) (immobilisation at $48 \mathrm{hrs,}$ ) against aquatic organisms

\begin{tabular}{|c|c|c|c|c|}
\hline \multicolumn{5}{|c|}{ a) On Artemia salina } \\
\hline Substance & $\begin{array}{l}\text { Sulfa- } \\
\text { methoxa- } \\
\text { zole }\end{array}$ & Diazinon & $\begin{array}{c}\text { Salix } \\
\text { cortex } \\
\text { bark }\end{array}$ & $\begin{array}{l}\text { Salix } \\
\text { cortex } \\
\text { leaves }\end{array}$ \\
\hline $\begin{array}{l}\text { EC50 (in mg } \\
\mathrm{ml}^{-1} \text { ) }\end{array}$ & $>0.1$ & 0.0013 & 3.1 & 3.7 \\
\hline \multicolumn{5}{|c|}{ b) On Daphnia pulex } \\
\hline Substance & $\begin{array}{l}\text { Triazole } \\
\text { benzo- } \\
\text { ylureas }\end{array}$ & Atrazine & $\begin{array}{c}\text { Salix } \\
\text { cortex } \\
\text { bark }\end{array}$ & $\begin{array}{l}\text { Salix } \\
\text { cortex } \\
\text { leaves }\end{array}$ \\
\hline $\begin{array}{l}\text { EC50 (in mg } \\
\mathrm{ml}^{-1} \text { ) }\end{array}$ & $\begin{array}{c}0.051 \text { to } \\
0.0000225\end{array}$ & 0.051 & 215 & 222 \\
\hline
\end{tabular}

The use of willow extract (Salix cortex) as a basic substance was approved by $71.46 \%$ of the $28 \mathrm{EU}$ (i.e. all except Germany and United Kingdom) Member States were for a "positive 
a) Bee mortality induced by feeding

Bee mortality induced by feeding in \%

Control $\square$ D/10 MD/5 $\square D / 5 \quad 3 D / 5 \quad 3 D / 5$

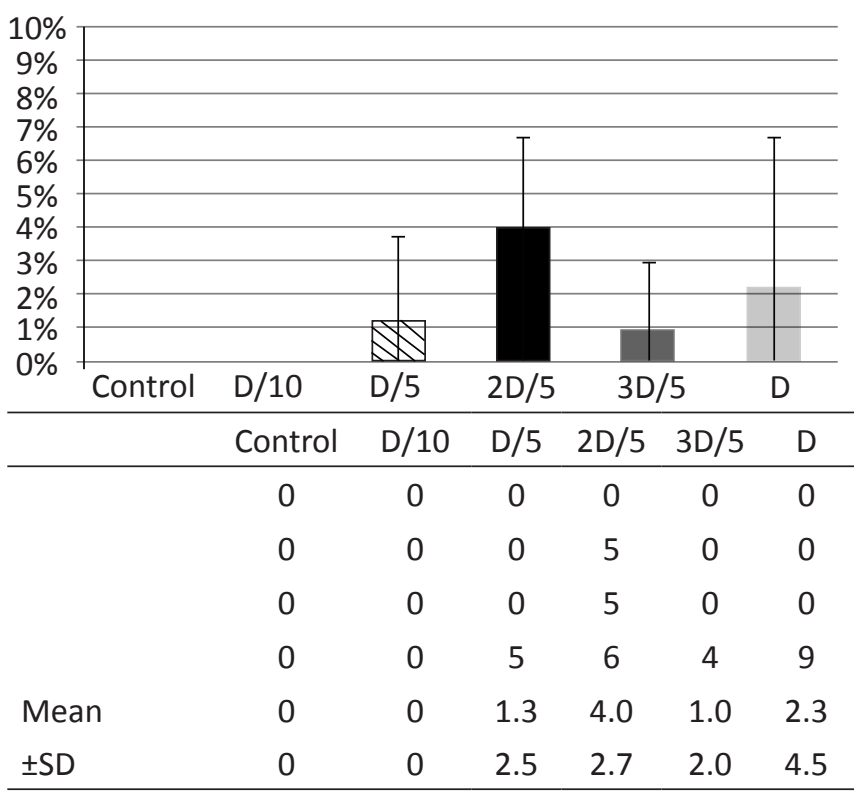

b) Bee mortality induced by contact

Bee mortality induced by feeding in \%

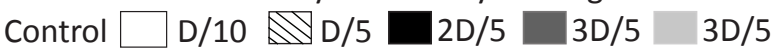

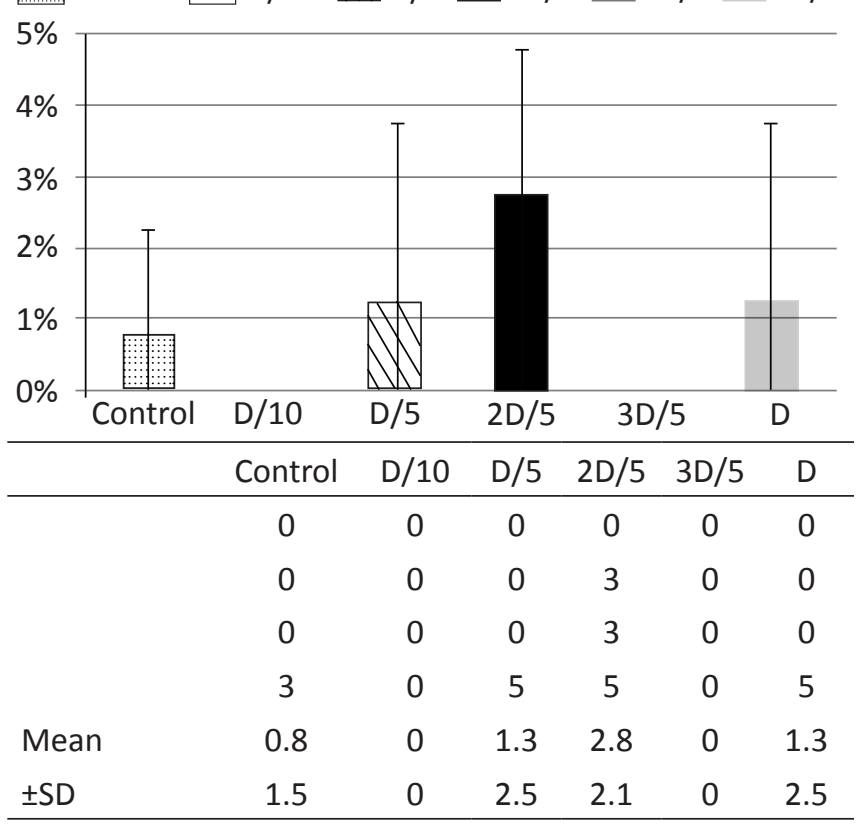

Figure 4: Toxicity of the willow preparation tested on the bees

issue of the BSA" therefore it was approved under Regulation EC $n^{\circ} 1107 / 09$ and included in EC 540/2011 (EU, 2015). The substance was then registered in EU pesticide database and the MRL fixed at 0 in Annex IV of EC Reg. 396/2005 (EU, 2016). This shows that initial work from " $4 \mathrm{P}$ " program was not only successful but incentive to other developments.

\subsection{Extensions at EU General Regulation}

The procedure for extending the uses of basic substance has already been described by our Institute (Marchand, 2017b). The application was undertaken accordingly for Salix cortex considering the root promoting effects of IBA, one of the active constituents contained in this extract. An extension of uses was therefore constituted, submitted in June 2018 with all information including the recipe modifications and the new GAP table. This extension was evaluated by the PAFF Committee in July and discussed in October.

A further use extension of Salix cortex for vegetable/fruit production as fungicide was submitted in September 2018 with independent results from field trials.

\subsubsection{Extending the uses of Salix cortex: Willow water used in plants cutting}

Willow water was widely used to facilitate the rooting of cuttings of all types of plants well before the discovery and chemical production of corresponding synthetic auxins, such as indole butyric acid. In this way, an extension of use for the approved basic substance Salix cortex has been submitted to the European Commission by our institute. This application concerns the use of willow water as a root growth stimulator for nursery cuttings. There is already an extensive literature existing, attesting to the effectiveness of the willow water as an aid to the successful rooting of cuttings; this ongoing application is essentially based on this published literature and the corresponding preparation recipe.

\subsubsection{Extending the uses of Salix cortex: extension for the vegetable and fruit markets}

A second extension for Salix spp. cortex as antifungal extract against Botrytis cinerera and Penicillium expansum for tomatoes, berries and kiwis has just been submitted. Like the previous extension, it is based on several previously published scientific articles, in vivo assays and field trials.

\subsection{From organic production regulation point of view}

Organic farming also allows some plant extract uses in the fertilizer compartment (Annex I) of the production regulation (EC, 2008). Some plant extract are already allowed in the plant protection compartment (Annex II). Later basic substances were included as specific category (EU, 2016b; Marchand, 2017a). Recently, the EGTOP Report (EGTOP, 2016) outcome about Salix cortex inclusion in Annexe II was positive, and a Vote for this issue was programmed at RCOP (Ares, 2018). Thus, Salix cortex extract is now legally available in EU for organic farmers as plant protection means (EU, 2018).

\section{Conclusion}

This global work showed the efficacy as plant protection means in field and the absence of concern of the substance in the environmental compartments (groundwater, bees and non-target organisms). All of this data, allowed the Salix cortex approval as basic substance with light fungicide properties under EU pesticide regulation and in organic farming. Trials were conducted to investigate new possible agricultural 
usages and some are already deposited as "extension uses" in order to be legally allowed (i.e. to plant nursery for root promotion and for market gardening).

\section{Further Research}

Some of the useful applications and usages in fields are already approved at EU level or under evaluation (for field and tree nurseries usages); however, further development and field trials are under investigation to expand the beneficial aspect of this plant protection substance.

\section{Acknowledgement}

The author wishes to thank Trevor M. Fenning for providing helpful advice on the editing and writing of the manuscript.

\section{References}

Alam, R., Rahman, K., Ilyas, M.I., Rauf, M., 2007. Effect of indole butyric acid concentrations on the rooting of kiwi cuttings. Sarhad Journal of Agriculture 23(2), 293-295.

Alfredsen, G., Solheim, H., Slimestad, R., 2008. Antifungal eVect of bark extracts from some European tree species. European Journal of Forest Research 127, 387-393.

Andreu, V., Levert, A., Amiot, A., Cousin, A., Aveline, N., Bertrand, C., 2018. Chemical composition and antifungal activity of plant extracts traditionally used in organic and biodynamic farming. Environmental Science and Pollution Research 25(30), 29971-29982.

Anonymous, 1992. USEPA- Reregistration Eligibility Document (RED) Indole-3-Butyric Acid. Available from: https:// archive.epa.gov/pesticides/reregistration/web/ pdf/2330fact.pdf [20 March 2019].

Anonymous, 2008. EC (2008). Commission Regulation (EC) No $889 / 2008$ of 5 September 2008 laying down detailed rules for the implementation of Council Regulation (EC) No 834/2007 on organic production and labelling of organic products with regard to organic production, labelling and control. 2008; L 250. Available from: http:// data.europa.eu/eli/reg/2008/889/oj [18 October 2018].

Anonymous, 2014. EFSA (2014). Outcome of the consultation with Member States and EFSA on the basic substance application for Salix alba bark and the conclusions drawn by EFSA on the specific points raised. European Food Safety Authority. EFSA supporting publication 2014:EN-609. 34.

Anonymous, 2015b. EU (2015b). Commission Implementing Regulation (EU) No 2015/1107 of 8 July 2015 approving the basic substance Salix spp. cortex, OJ L 181, of 9.7.2015, 72-74.

Anonymous, 2016a. EU (2016a). Commission Implementing Regulation (EU) 2016/143 of 18 January 2016 amending Annex IV to Regulation (EC) No 396/2005 of the European Parliament and of the Council as regards COSOGA, cerevisane, calcium hydroxide, lecithins, Salix spp cortex, vinegar, fructose, Pepino mosaic virus strain $\mathrm{CH} 2$ isolate 1906, Verticillium albo-atrum isolate WCS850 and Bacillus amyloliquefaciens subsp. plantarum strain D747, OJ L 28, of 4.2.2016, 12-14.

Anonymous, 2016b. EU (2016b). Commission Implementing Regulation (EU) 2016/673 of 29 April 2016 amending Regulation (EC) No 889/2008 laying down detailed rules for the implementation of Council Regulation (EC) No $834 / 2007$ on organic production and labelling of organic products with regard to organic production, labelling and control. OJ L 116 of 30.4.2016, 8-22. Available from: https://eur-lex.europa.eu/legal-content/EN/TXT/ PDF/?uri=CELEX:32016R0673 [18 October 2018].

Anonymous, 2017. EGTOP (2017). Final report on plant protection products (III), Expert group for technical advice on organic production. Available from: https:// ec.europa.eu/agriculture/organic/sites/orgfarming/ files/egtop_plant_protection_iii-2016-10-26-definitive_ version.pdf [18 October 2018].

Anonymous, 2017. EMA (2017). Assessment report on Salix [various species including S. purpurea L., S. daphnoides Vill., S. fragilis L.], cortex. EMA/HMPC/80628/2016 Available from: https://www.ema.europa.eu/ documents/herbal-report/final-assessment-reportsalix-various-species-including-s-purpurea-I-sdaphnoides-vill-s-fragilis-I_en.pdf [18 October 2018].

Anonymous, 2018. EUR-Lex. Ares (2018). available at https:// eur-lex.europa.eu/legal-content/EN/TXT/?uri=PI_ COM:Ares(2018)3342965

Anonymous, 2018. EU Health and Consumers Director General (2014). WORKING DOCUMENT on the procedure for application of basic substances to be approved in compliance with Article 23 of Regulation (EC) No 1107/200SANCO/10363/2012 Rev. 9. [Online]. Available: https://ec.europa.eu/food/sites/food/files/plant/docs/ pesticides_ppp_app-proc_basic-subst_guidance.pdf [18 October 2018].

Anonymous, 2018. EU (2018). European Union. Commission Implementing Regulation (EU) 2018/1584 of 22 October 2018 amending Regulation (EC) No 889/2008 laying down detailed rules for the implementation of Council Regulation (EC) No 834/2007 on organic production and labelling of organic products with regard to organic production, labelling and control. OJ L 264 of 23.10.2018, p. 1-12. Available from: https://eur-lex.europa.eu/legal-content/EN/TXT/ PDF/?uri=CELEX:32018R1584\&from=EN [1 November 2018].

Anonymous, 2019. DG Health and Food Safety. 2019. EU Pesticides database, http://ec.europa.eu/ food/plant/pesticides/eu-pesticides-database/ public/?event=download.MRL [18 June 2019].

Anonymous, 2019. EMA (2019). Assessment report on Salicis cotex (Willow bark) and herbal preparation(s) thereof with well-established use and traditional use. EMEA/ 
HMPC/295337/2007, European Medicines Agency, 2009, 1-27.

Argus, G., 1997. Infrageneric classification of Salix (Salicaceae) in the new world. American Society of Plant Taxonomists. $52,1-121$.

Arif, T., Bhosale, J.D., Kumar, N., Mandal, T.K., Bendre, R.S., Lavekar, G.S., Dabur, R., 2009. Natural products: Antifungal agents derived from plants. Journal of Asian Natural Products Research 7, 621-38.

Anonymous, 1984. OECD, Daphnia sp., Acute Immobilisation Test and Reproduction Test. OECD Guidelines for testing chemicals No 202, 1-16.

Banik, S., Maiti, R., 2016. Biotic Stress: Diseases. In: Maiti R., Kumari A., Thakur A., Sarkar N. (Eds.), Bioresource and Stress Management. Springer, Singapore, 87-99.

Bertoni, G., 2011. Indolebutyric Acid-Derived Auxin and Plant Development. The Plant Cell 23(3), 845.

Dempsey D'Maris, A., Klessig, D.F., 2017. How does the multifaceted plant hormone salicylic acid combat disease in plants and are similar mechanisms utilized in humans? BMC Biology 15(23), 1-11.

Fuster, V. et al. 2011. Aspirin: A Historical and Contemporary Therapeutic Overview. Circulation 123, 768-778.

Gilliver, K., 1947. The effect of plant extracts on the germination of the conidia of Venturia inaequalis. Annals of Applied Biology, 34(1), 136-143.

Hussain, H. et al., 2011. Chemical constituents and antimicrobial activity of Salix subserrata. Records of Natural Products 5, 133-137.

Kast, W.K., 2002. Effects of plant extracts on downy mildew of vine-laboratory and field experiments. 10th International Conference on Cultivation Technique and Phytopathological Problems in Organic Fruit Growing and Viticulture Proceedings of a conference, Weinsberg, Germany, 4-7 February 2002: 157-162. Available from: http://orgprints.org/14619/1/kast_157.pdf [20 March 2019].

Levesque, H., Lafont, O., 2000. L'aspirine a travers les siècles: Rappel historiqueAspirin throughout the ages: an historical review. La Revue de Medecine Interne, 21(Supl. 1), S8-S17.

Maiti, R., Kumari, A., 2016. Natural Resource Management. In: Maiti R., Kumari A., Thakur A., Sarkar N. (Eds), Bioresource and Stress Management. Springer, Singapore, 33-51.

Marchand, P., Isambert, C., Jonis, M., Parveaud, C-E., Chevolon, M., Gomez, C., Lambion, J., Ondet, S., Aveline, N., Molot, B., Berthier, C., Furet, A., Clerc, F., Rey, A., Navarro, J-F., Bidault, F., Maille, E., Bertrand, C., Andreu, V., Treuvey, N., Pierre, S., Coulon, A., Chaput, C., Arufat, A., Brunet, J-L., Belzunces, L., Bonafos, R., Guillet, B., Conseil, M., Prieur, L., Tournant, L., Oste, S., Larrieu, J-F., Coulombel,
A., 2014. Evaluation des caracteristiques et de l'interet agronomique de preparations simples de plantes, pour des productions fruitières, legumières et viticoles economes en intrants. Innovations Agronomiques 34, 83-96.

Marchand, P., 2015. Basic substances: an opportunity for approval of low-concern substances under EU pesticide regulation. Pest Management Science 71(9), 1197-2000.

Marchand, P., 2016. Basic substances under EC 1107/2009 phytochemical regulation: experience with non-biocide and food products as biorationals. Journal of Plant Protection Research 56(3), 312-318.

Marchand, P., 2017a. Basic Substances under EU Pesticide Regulation: an opportunity for Organic Production? Organic Farming 2017 3(1), 16-19.

Marchand, P., 2017b. Basic and Low risk Substances under EU pesticide regulation: A new choice for biorationals portfolio of Small and Medium-sized Enterprises. Journal of Plant Protection Research 57(4), 433-440.

Marchand, P., 2017c. Basic substances as renewable and affordable crop protection products. Chronicle of Bioresource Management 1(2), 065-066.

Potter, C., 1952. An improved apparatus for applying direct sprays and surface films with data on the electrostatic charge on atomize spray fluids. Annals of Applied Biology 39, 1-28.

Qaddoury, A., Amsa, M., 2004. Effect of exogenous indole butyric acid on root formation and peroxidase and indole-3-acetic acid oxidase activities and phenolic contents in date Palm offshoots. Botanical BulletinAcademia Sinica Taipei 45, 127-131.

Rocha Neto, A., Maraschin, M., Di Piero, R., 2015. Antifungal activity of salicylic acid against Penicillium expansum and its possible mechanisms of action. International Journal of Food Microbiology 215, 65-70.

Tajbakhsh, M., Korkan, M., Ghiyasi, M., 2009. Effect of timing on callus formation and rooting ability in IBA-treated hardwood stem cuttings of persian walnut, hazelnut and apple. Notulae Botanicae Horti Agrobotanici Cluj-Napoca 37(1), 103-107.

Tosun, N., Aktas, L., Karabay Yavasoglu, N.U., Turkusay, H., 2003. Effects of salicylic acid, harpin and phosphorus acid in control of late blight (Phytophthora infestans Mont. De Barry) disease and some physiological parameters of tomato. Turkish Phytopathological Society 32(3), 165-174.

Vegephyl. 2018. Liste des methodes C.E.B. octobre 2018. Available from: http://www.afpp.net/apps/accesbase/ bindocload. asp? $d=7743 \& \mathrm{t}=0$ \&identobj=EOZreKcP\&ui $d=57305290 \&$ sid=57305290\&idk=1 [20 March 2019]. 